\title{
Senile squalor: Plyushkin's not Diogenes' syndrome
}

\author{
E. Cybulska
}

Some names appear to stick to syndromes or diseases like a proverbial glue, regardless of their total inappropriateness. Gross self-neglect in old age characterised by domestic squalor, social withdrawal, apathy, tendency to hoard rubbish (syllogomania) and a lack of shame was originally reported by Macmillan \& Shaw in 1966 and subsequently 'christened' by Clark et al as Diogenes' syndrome in 1975. Post (1982) preferred the term 'senile recluse' and argued that this is not a syndrome but merely an end stage of personality disorder. It was usually extremely difficult to help these patients, as one's care and goodwill often met with hostility and blunt refusal to cooperate (Cybulska \& Rucinski, 1986). More recent studies, however, have shown a strong association of this condition with frontal lobe dysfunction (Orrell \& Sahakian, 1991), thus giving a psychiatrist of old age a somewhat firmer basis for action.

It is high time to exonerate Diogenes of Sinope, a Greek philosopher of the fourth century BC, from any relationship with the above predicament. As a prototype of cynism, Diogenes advocated self-sufficiency, freedom from social restrain and rejection of all luxury. He regarded happiness as a quality possessed within oneself, unrelated to material wealth and status. He lived as he preached, sleeping rough in public buildings (some believe in a barrel) and begging for food, thus reducing his earthly needs to the barest minimum. He was said to venture daily to the market place with a lighted lantern in broad daylight in search of an honest man.

The patients with severe self-neglect are certainly far from happy, self-sufficient and least of all in search of company. On the contrary they are often described as angry, suspicious, reclusive and buried under an abundance of inanimate objects, dirt and dust. Miss Havisham from Dickens' Great Expectations might be a better example of the syndrome, but a more convincing description still can be found in Gogol's novel Dead Souls. Plyushkin, a widowed Russian aristocrat can hardly be challenged for the title:
The room was dark and only barely lit by a bright light coming from a big crack at the bottom of the door .... It looked as though they were springcleaning in the house and that all the furniture were piled up in this room. There was even a broken chair on one of the tables and next to it a clock with a stationary pendulum on which a spider had already spun its web ... On the bureau, inlaid with a mosaic of mother-of-pearl, which had fallen out in places . . . lay a large number of all sorts of things: a heap of closely written scraps of papers, covered with a marble egg-shaped paperweight, green with age, some kind of an ancient book, dried up lemon no larger than a hazel nut, a broken off arm of a chair, a wine glass containing some liquid and three flies ... a rag that had been picked up somewhere, two inkstained quills, dried up as though from consumption. a toothpick yellow with age, which the master must have used to pick his teeth with before the French occupation of Moscow . . .

His (Plyushkin's) clothes were far more remarkable: by no possible methods and by no effort could one discover what his dressing gown was made of; the sleeves and the upper part of the shirt were so greasy and shiny that they looked like the soft leather of which Russian boots are made; at the back instead of two tails there were four out of which cotton wool hung in tufts. There was also something tied around his neck. It was impossible to make out whether it was a stocking, a garter, or an abdominal band, but it certainly could not be a neck-tie . . .

He wandered about the streets of his village every day looking under the bridges, under the planks thrown over the puddles, and everything he came across, an old sole, a bit of a peasant woman's rags. an iron nail, a piece of broken earthware, he carried them all to his room and put them on the heap ... All this was put away in the store houses and got mouldy and full of gaping holes and in the end he himself became a gaping hole in human-kind ...

(from Dead Souls by N. Gogol) 
Gogol, N. (1961) Dead Souls, pp. 120-128. London: Penguin.

Macmillan, D. \& Shaw, P. (1966) Senile breakdown in standards of personal and environmental cleanliness. British Medical Journal, it, 1032-1037.

ORRELL, M. W. \& SAHAKIAN, B. J. (1991) Dementia of frontal lobe type. Psychological Medicine, 21. 553-556.
Post, F. (1982) Functional Disorders. In Psychiatry of Late Life (eds R. Levy \& F. Post), pp. 176-196. Oxford: Blackwell Scientific.

E. Cybulska, Consultant Psychiatrist, Thameslink Healthcare Services, Stone House, Cotton Lane, Dartford, Kent DA2 6AU

\section{New Occasional Papers}

OP40 Community Psychiatric Nursing, £5.00, February 1998

Revision of 1980 Discussion Document of Community Psychiatric Nursing. Reviews the development of Community Mental Health Nursing and current issues relating to their role in the provision of care for those with mental illness.

OP41 Management of Imminent Violence, $£ 20.00$ (£10.00 to Members quoting Membership No.), March 1998

Clinical practice guidelines to support mental health services. Essential reading for all clinicians, managers and directors.

OP43 Higher Specialist Training Handbook, £7.50, March 1998

Eighth edition and the first to be produced under the newly constituted Higher Specialist Training Committee.

Available from Booksales, Royal College of Psychiatrists, 17 Belgrave Square, London SWIX 8PG (Tel. +44 (0)171 2352351 , extension 146). The latest information on College publications is available on the INTERNET at: www.rcpsych.ac.uk 